\title{
Centrolobium tomentosum: macro- and microscopic diagnosis of the leaf and stem
}

\author{
Marianna Erbano, Márcia R. Duarte*
}

Programa de Pós-graduação em Ciências Farmacêuticas, Laboratório de Farmacognosia, Departamento de Farmácia, Universidade Federal do Paraná, Brazil.

\begin{abstract}
Centrolobium tomentosum Guillemin ex Benth., Fabaceae, known as "araribá-rosa", is a large tree that is widespread throughout Brazil. The bark of its stem is used in folk medicine as an astringent and the leaves are employed as a poultice for wounds and bruises. The aim of this study was to contribute to the pharmacognostic quality control of this medicinal species through a macro- and microscopic diagnosis of its leaves and stems. Mature leaves and young stems were collected at Embrapa (Colombo, PR) and analyzed using standard microtechniques. The leaves are opposite or alternate, compound, imparipinnate, oblong-lanceolate and hypostomatic with paracytic stomata. The mesophyll is dorsiventral and the midrib is biconvex with a collateral vascular bundle in a circular arrangement. The petiolule is circular and its vascular system is composed of two major vascular bundles in the middle, with smaller bundles between them. The rachis has a structure similar to the petiole, and these parts have a sclerenchymatic sheath shaped in multiple arcs, which surrounds a collateral vascular bundle that is centrally located. The stem has a uniseriate epidermis with peripheral phellogen and a sclerenchymatic sheath composed of many arcs, which surrounds the phloem. The stems and leaves also have non-glandular and glandular trichomes, phenolic compounds and idioblasts made of calcium oxalate crystals. This manuscript has an important role in the morpho-anatomical diagnosis of the Brazilian flora.
\end{abstract}

Revista Brasileira de Farmacognosia Brazilian Journal of Pharmacognosy 22(2): 249-256, Mar./Apr. 2012

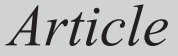

Received 11 Aug 2011

Accepted 12 Out 2011

Available online 29 Nov 2011

Keywords: araribá-rosa

Centrolobium tomentosum Fabaceae medicinal plant morpho-anatomy

ISSN 0102-695X http://dx.doi.org/10.1590/S0102$695 \times 2011005000218$

\section{Introduction}

The family Fabaceae has three major subfamilies: Mimosoideae, Caesalpinioideae and Faboideae (Judd et al., 2008). In Brazil there are approximately 178 genera and 1550 species (Bertoluzzi et al., 2006) of Fabaceae, and many of these taxa are used in landscaping, foods, folk medicines and by the pharmaceutical industry (Souza \& Lorenzi, 2005; Judd et al., 2008).

The genus Centrolobium Mart. is exclusive to the Neotropics (Lima, 1983-1985), and mainly occurs in Bolivia and Brazil (Tropicos, 2009). Centrolobium tomentosum Guillemin ex Benth., which belongs to subfamily Faboideae, is a tree (Figure 1A) that can reach $35 \mathrm{~m}$ tall (Lima, 1983-1985), and is native to South-Central Brazil (Tropicos, 2009). This species is popularly known as "araribá-rosa" or "araruva" and it is employed in afforestation (Lorenzi, 2002), in dyes and in folk medicine. The bark of its stem is used as an astringent and the leaves as a poultice for wounds and bruises (Corrêa, 1984).

Chemical studies of $C$. tomentosum have found tannins in the bark (Bastos, 1952), and Aragão-Craveiro et al. (1970) isolated diaryl-heptanoid compounds from the stem, such as centrolobine, des- $O$-methyl-centrolobine and centrolobol. These compounds have been shown to be active against the promastigote form of Leishmania amazonensis, which is the causative agent of cutaneous leishmaniasis, an endemic disease in some regions of Brazil (Araujo et al., 1999).

Due to the few studies concerning the morphological and anatomical profile of C. tomentosum, the goal of this study was to produce macroscopic and microscopic diagnosis of the leaf and stem of this medicinal species, in order to contribute to the pharmacognosy quality control of this species and to what is known about the Brazilian flora.

\section{Material and Methods}

\section{Plant material}

In September 2008, the plant material Centrolobium tomentosum Guillemin ex Benth., Fabaceae, was collected from specimens growing in sunny areas at the Empresa Brasileira de Pesquisa Agropecuária (Embrapa), located in Colombo, Paraná, Brazil $\left(25^{\circ} 17^{\prime} \mathrm{S}, 40^{\circ} 13^{\prime} \mathrm{W}, 950 \mathrm{~m}\right.$ elevation). The 
voucher specimen was identified and deposited in the Fernando Cardoso Herbarium as HFC 1197. The external morphology of the leaves was based on Hickey (1974) and the leaf dimensions were calculated based on the average measurements of at least twenty leaflets and the anatomical morphology was based on Metcalfe \& Chalk (1950).

Assays

Mature leaves and young stem fragments (5-25 $\mathrm{cm}$ from the stem apex) were fixed in FAA70 (Johansen, $1940)$ and stored in 70\% (v/v) ethanol (Berlyn \& Miksche, 1976). To prepare semi-permanent slides, freehand sections (transverse, longitudinal and paradermal) of the material previously fixed in FAA70 were stained either with astra blue and basic fuchsine (Roeser, 1972) or with toluidine blue (O'Brien et al., 1964). Permanent slides were prepared from the fixed material, dehydrated in an ethanol series ( 80 and $95 \% \mathrm{v} / \mathrm{v}$ ), embedded in synthetic resin, sectioned with a rotary microtome and stained with toluidine blue (Kraus \& Arduin, 1997).

For the microchemical tests, the following reagent solutions were used: Sudan III to verify cutin, oil and fat (Sass, 1951); lugol for starch (Berlyn \& Miksche, 1976); ferric chloride for phenolic compounds (Johansen, 1940); phloroglucin for lignin (Foster, 1949); and sulphuric acid for calcium salt crystals (Oliveira et al., 1991).

The ultrastructural analysis of the leaf surface, using scanning electron microscopy, was performed with samples fixed in FAA70. The studied material was dehydrated twice, first in an increasing ethanol series (80, 90 and $100 \% \mathrm{v} / \mathrm{v}$ ) and then in a critical point dryer. The samples were then coated with gold, and examined and photographed with a scanning electron microscope (Souza, 2007).
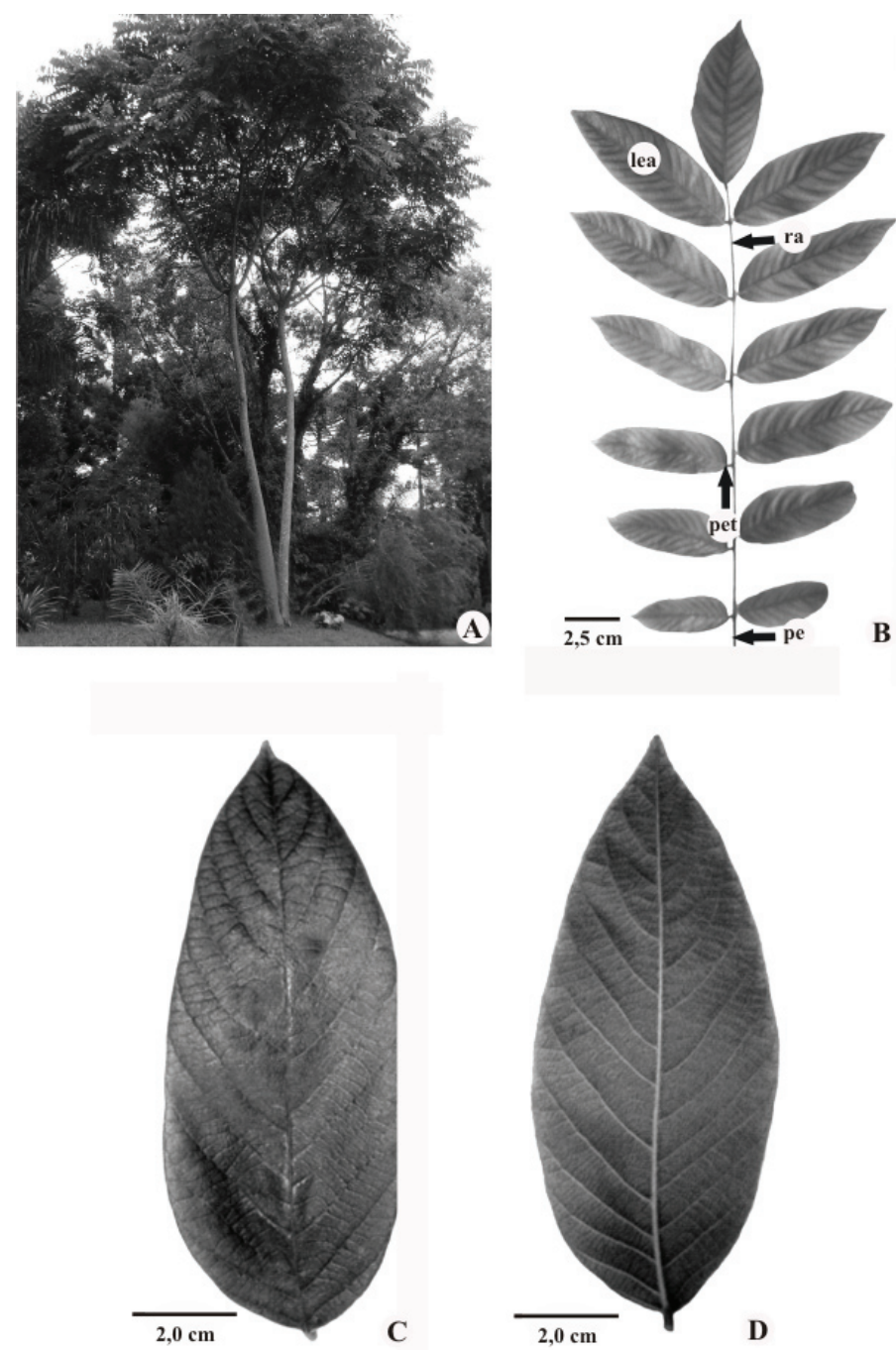

Figure 1. Centrolobium tomentosum Guillemin ex Benth., Fabaceae. Leaf: A. In the natural habitat; B. Overall aspect of the composite leaf; C. Adaxial surface of the leaflet; D. Abaxial surface of the leaflet. Abbreviations: lea: leaflet, pe: petiole, pet: petiolule, ra: rachis. 


\section{Results}

Macroscopic diagnosis

The leaves are opposite or alternate, compound, imparipinnate, and have 13-19 leaflets (Figure 1B). The petiole is about $8 \mathrm{~cm}$ long. The rachis, which is the main axis of the leaf, is approximately $36 \mathrm{~cm}$ and the petiolule has mean length of $0.5 \mathrm{~cm}$ (Figure 1B). The leaflets are opposite or alternate, symmetrical to slightly asymmetrical, with a smooth margin (Figures 1B-1D). The average size of the leaflets is $10 \mathrm{~cm}$ long $\times 4 \mathrm{~cm}$ wide, which are usually ovate to oblong-lanceolate (Figures 1B-1D). Most leaflets have an acute apex (Figure 1D); however, there are some that have indentations, forming an emarginate apex. The base of the leaflets varies from obtuse to round (Figures 1C, 1D). The surface of the leaflets is tomentose, as well as other parts of the leaf, and the laminar texture is subcoriaceous.

The venation pattern is pinnate (Figure 1D), with secondary veins departing from the midrib, and is subclassified as camptodromous-brochidodromous venation, in which the veins are interconnected in a series of prominent arcs near the margin.

\section{Microscopic diagnosis}

\section{Leaf}

In face view of the leaflet blade, the epidermal cells are polygonal to slightly wavy on both surfaces (Figures 2A, 2B). The cuticle, which has lipophilic substances, is smooth for almost the whole length, with slightly striated ornamentation near the base of each trichome (Figure 2C).

Multicellular, long and thin walled, trichomes (Figures 2D, 2E) occur on both epidermal surfaces. The base of these trichomes is composed of relatively small cells, and the apical cells are elongate and acute (Figure 2D). On the abaxial surface there are multicellular, peltate, glandular trichomes. These are inserted in epidermal depressions (Figure 2E).

The stomata are paracytic. They have two subsidiary cells parallel to the guard cells (Figure 2B). These epidermal appendices have external cuticular ledges (Figure 2C) and the stomata are restricted to the abaxial surface, characterizing the leaf as hypostomatic.
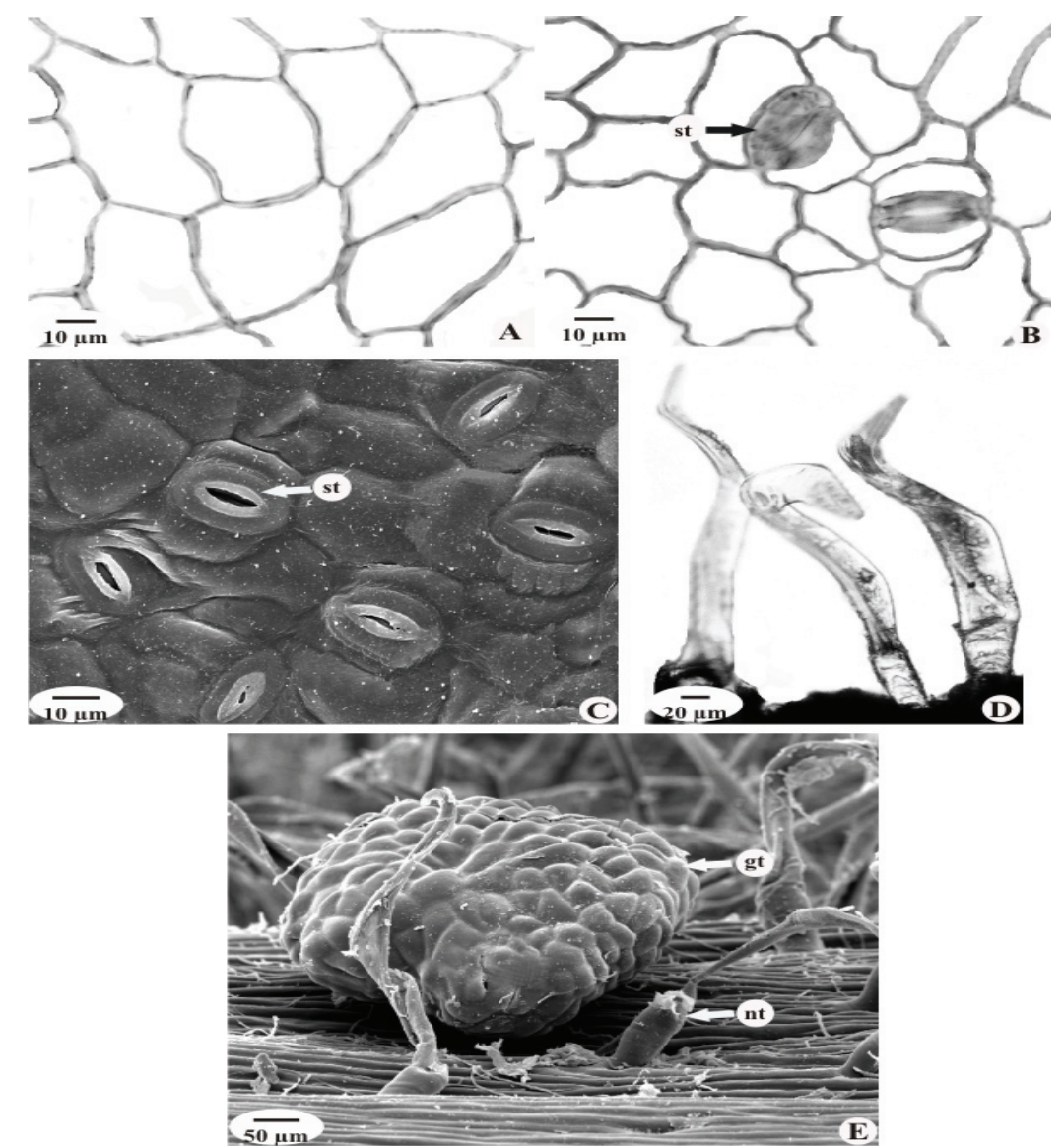

Figure 2. Centrolobium tomentosum Guillemin ex Benth., Fabaceae. Leaf, in face view: A. Epidermal cells of the adaxial surface; B. Epidermal cells of the abaxial surface with stomata; C. Stomata of the abaxial surface; D. Non-glandular trichomes; E. Non-glandular and glandular trichomes. Abbreviations: gt: glandular trichome, nt: non-glandular trichome, st: stomatum. 
In transverse section, the epidermis is uniseriate, revealing adaxial cells comparatively larger than those of the opposite surface (Figures 3A, 3B), and covered with a thin cuticle. The stomata are found at the same level as the epidermal cells (Figure 3A).

The mesophyll is dorsiventral, consisting of approximately two layers of palisade cells along the adaxial side, representing $60 \%$ of the height of the photosynthetic parenchyma, and two to four layers of spongy parenchyma on the opposite side (Figures 3A, 3B). Vascular bundles of small and medium size are distributed throughout the mesophyll (Figure 3B), and surrounded by a sclerenchymatic sheath.
The midrib is biconvex in cross section, with two or three small projections on the abaxial side (Figure 3C). Below the epidermis, there are few layers of collenchyma (Figure 3D). Several vascular bundles are centrally arranged (Figure 3C) and all of the bundles are surrounded by a thick sclerenchymatic sheath consisting of fibers (Figures 3C-3E).

The petiolule (Figures 4A, 4B), in cross section, is circular in shape. The epidermis is uniseriate and covered with a slightly thickened cuticle (Figure 4A). There are multicellular, long and thin walled trichomes and, inserted in epidermal depressions, there are multicellular peltate glandular trichomes (Figure
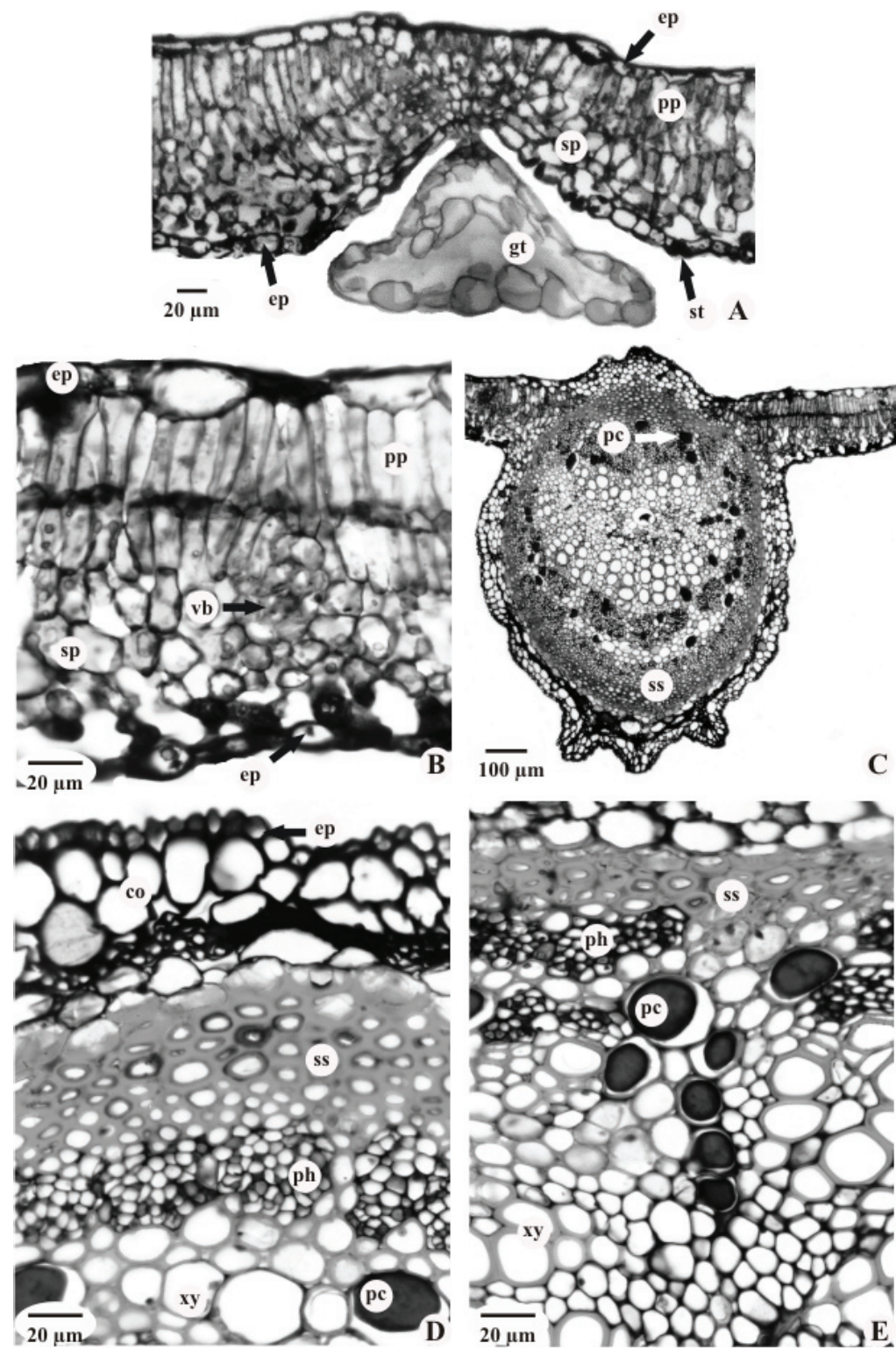

Figure 3. Centrolobium tomentosum Guillemin ex Benth., Fabaceae. Leaf, in transverse section. A. Intervein region, showing glandular trichome; B. Detail of dorsiventral mesophyll and a minor vascular bundle; C. Overall appearance of the midrib; D, E. Detail of the sclerenchymatic sheath, collateral vascular bundle and idioblasts with phenolic compounds. Abbreviations: co: collenchyma; ep: epidermis, gt: glandular trichome, pc: phenolic compounds, ph: phloem, pp: palisade parenchyma, sp: spongy parenchyma, ss: sclerenchymatic sheath, vb: vascular bundle, xy: xylem. 
4A). There are few layers of annular collenchyma and various strata of ground parenchyma (Figures 4A, 4C). The vascular system of the petiolule has a sclerenchymatic sheath (Figures 4A, 4B), and the system (Figure 4D) is composed of two major vascular bundles in the middle, with smaller bundles between them (Figure 4A).

The rachis has a structure similar to the petiole. The rachis (Figure 5A) and petiole, in cross section, are circular in shape. The epidermis is uniseriate and covered with a thin cuticle. Throughout the rachis and petiole there are multicellular trichomes with acute apices and thin walls. The collenchyma, below the epidermis, has a few cell layers of the annular type (Figure 5B). The vascular system of the rachis and petiole is entirely surrounded by a lignified sclerenchymatic sheath composed of many arcs (Figure 5A). The vascular system is collateral, centrally arranged and has phloem with sieve elements and parenchyma. The xylem has tracheary elements and lignified ray parenchyma (Figure 5A). Near the periphery of the pith there are some parenchyma cells in early stages of lignification.

Phenolic compounds (Figures 3C-3E, 4A, 5A) are present mainly in the vascular system of all parts of the leaf. Amyloplasts are generally found in the ground parenchyma and phloem. Druses and prisms of calcium oxalate are also observed throughout the leaf.
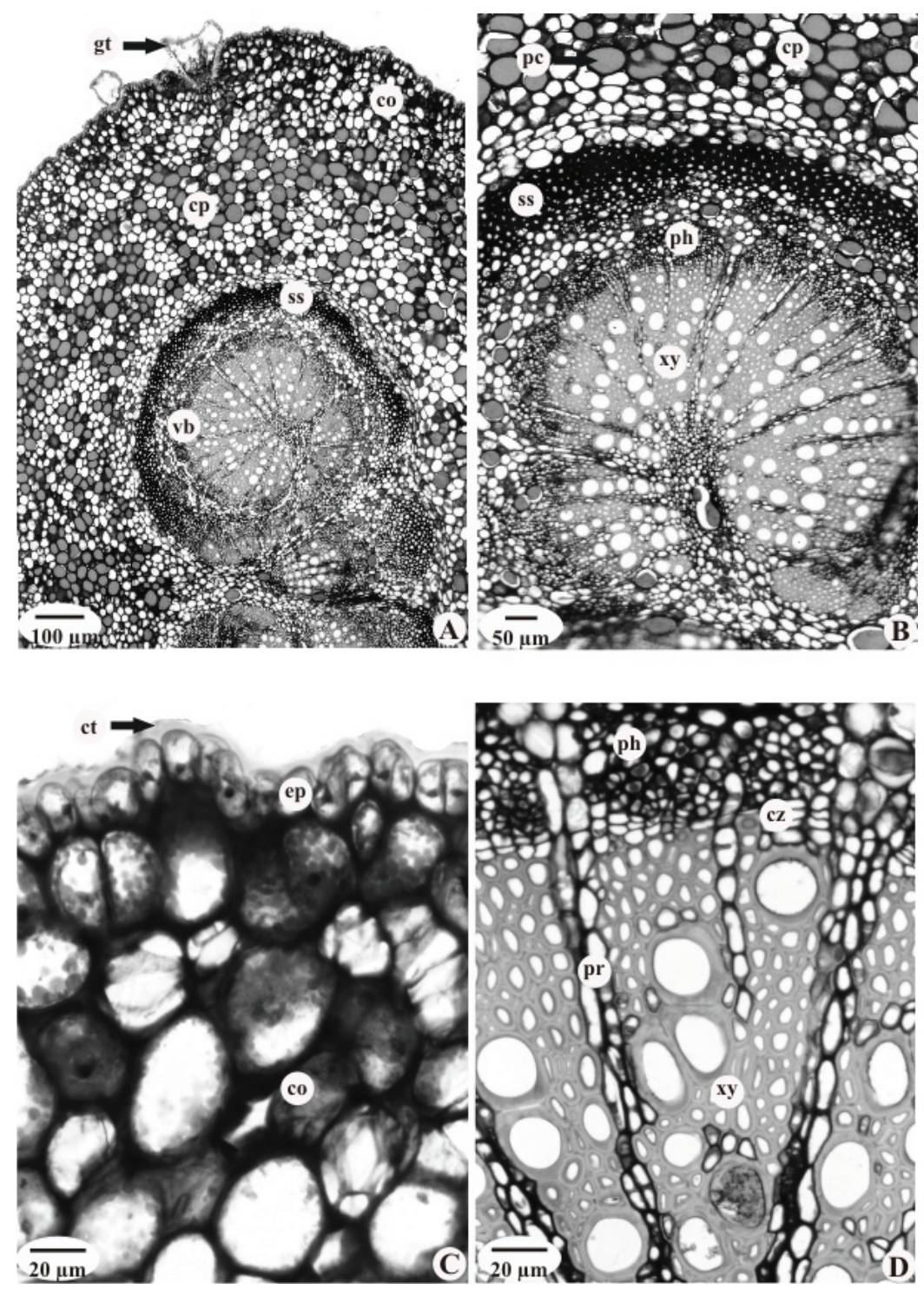

Figure 4. Centrolobium tomentosum Guillemin ex Benth., Fabaceae. Petiolule, in transverse section: A. Overall appearance; b. Detail of the petiolule; C. Detail of the cuticle, epidermis and collenchyma; D. Collateral vascular bundle. Abbreviations: co: collenchyma, cp: cortical parenchyma, ct: cuticle, cz: cambial zone, ep: epidermis, gt: glandular trichome, pc: phenolic compounds, ph: phloem, pr: parenchymatic ray, ss: sclerenchymatic sheath, vb: vascular bundle, xy: xylem. 
In cross section, the stem (Figure 5C) is circular in shape. The epidermis is uniseriate and covered with a thin cuticle which has lipophilic substances. Trichomes on the stems are structurally similar to those found on the leaves. Phellogen is also present on the outer portion of the stems.

In the cortex, there are annular collenchyma and a multistratified cortical parenchyma (Figure 5C). The collateral vascular cylinder is surrounded by a sclerenchymatic sheath that is composed of fibers and formed of continuous multiple arcs (Figures 5C, 5D). Narrow parenchymatic rays traverse both the phloem and xylem cylinders (Figures 5C, D).

Idioblasts containing phenolic compounds (Figure 5C) are present in the cortical parenchyma vascular system and pith. Prisms of calcium oxalate are also observed.
Considering the external leaf morphology observed in this study, Centrolobium tomentosum Guillemin ex Benth., Fabaceae, has features similar to those reported by Von Martius et al. (1840-1906), Corrêa (1984), Lorenzi (2002) and Filardi et al. (2007) for this species.

The species analyzed in this investigation reveals structural aspects consistent with the Faboideae (Fabaceae), presenting glandular and non-glandular trichomes, paracytic stomata, dorsiventral mesophyll and prisms of calcium oxalate in the leaves (Metcalfe \& Chalk, 1950). Metcalfe \& Chalk (1950) mention typical features of Centrolobium, such as the occurrence of multicellular uniseriate trichomes, with short basal cells and an elongated apical cell, and peltate glandular trichomes, which is in correspondence with what was observed in the present study. The figure presented by Metcalfe \& Chalk (1950) of
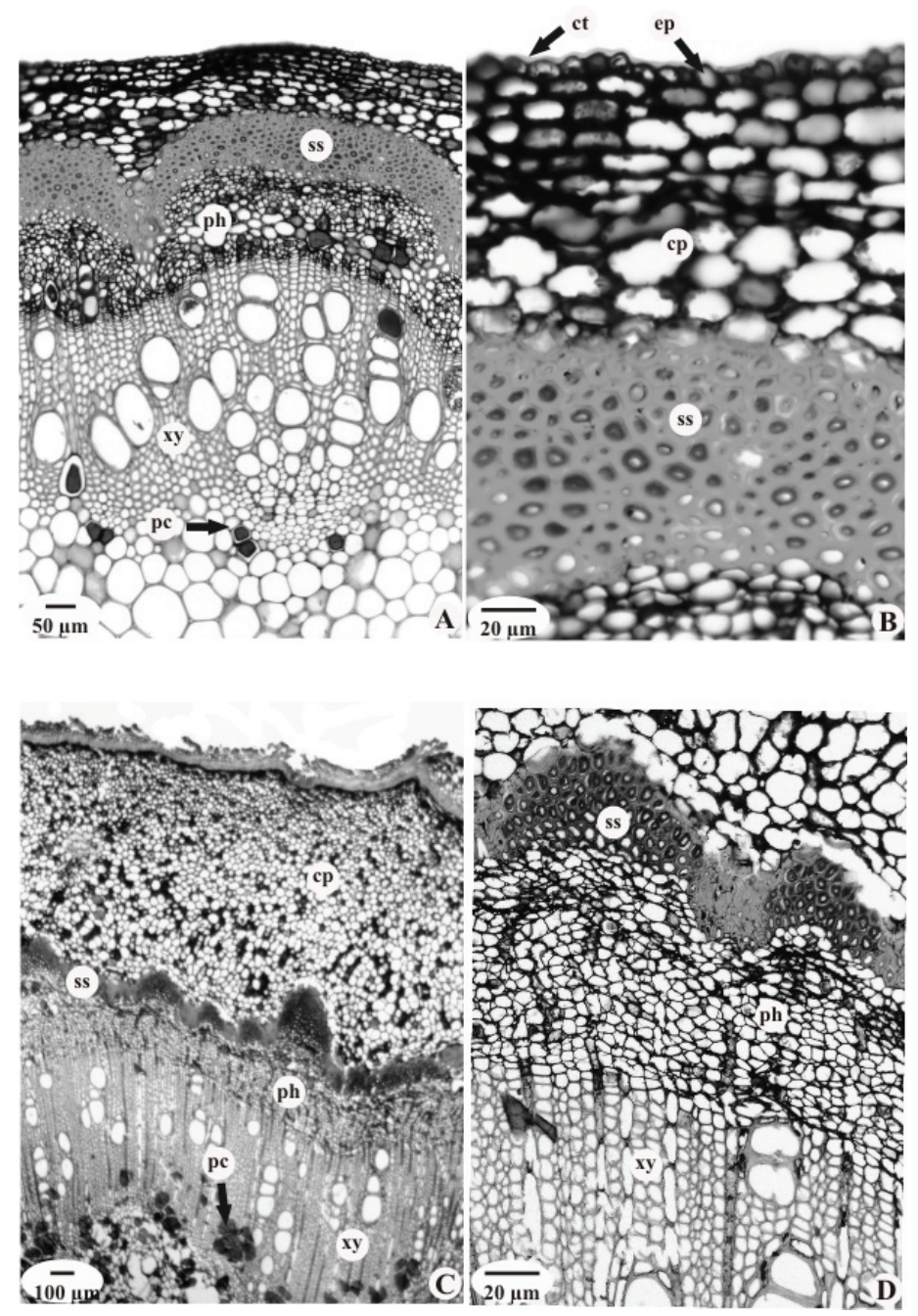

Figure 5. Centrolobium tomentosum Guillemin ex Benth., Fabaceae. A. Overall appearance of the petiole, in transverse section; B. Detail of the cuticle, epidermis, collenchyma and sclerenchymatic sheath; C. Overall appearance of the stem; D. Detail of the stem, showing part of the sclerenchymatic sheath and vascular system. Abbreviations: co: collenchyma, cp: cortical parenchyma, ct: cuticle, ep: epidermis, pc: phenolic compounds, ph: phloem, ss: sclerenchymatic sheath, xy: xylem. 
peltate glandular trichomes located in a small depression of the epidermis of C. robustum Mart. resembles the same structure that was observed in C. tomentosum.

When comparing the anatomy of other medicinal taxa of the Faboideae, Indigofera microcarpa Desv. "anileira" has leaflets with lignified filiform trichomes, different categories of stomata on both epidermal surfaces, styloid crystals and a vascular bundle in an open arc in the midrib (Lima et al., 2003), which are characteristics that are not found in C. tomentosum. Additionally, for Indigofera suffruticosa Mill. and I. truxillensis Kunth. the presence of forked trichomes and a granular cuticle are also important distinguishing features (Barros \& Teixeira, 2008).

Marquiafável et al. (2007) analyzed the content of secretory cells of species of Indigofera L. and observed that these cells contain alkaloids and phenolic compounds. The finding of this second group of compounds, comprising mainly tannins and flavonoids, was also found in $C$. tomentosum in the present investigation.

For Erythrina velutina Willd. "mulungu", the distinguishing characters are amphistomatic leaves, stellate trichomes and vascular bundles centrally arranged in the midrib (Ventura et al., 2006). Except for the trichomes, these characteristics are also found in E. cristagalli $\mathrm{L}$. (Gratieri-Sossella, 2005), which has a distinctly papillose epidermis on the abaxial surface.

In relation to the stem, peripheral phellogen and a continuous sclerenchymatic sheath are mentioned for Centrolobium by Metcalfe and Chalk (1950), and the present study confirmed that these characteristics occur in C. tomentosum.

This diagnosis of $C$. tomentosum aimed to identify and characterize morpho-anatomical and microchemical characteristics of this species in order to contribute to the quality control of this medicinal plant.

\section{Acknoeledgments}

To Embrapa-Florestas staff for the collection of the specimens and the Centro de Microscopia Eletrônica (UFPR) for providing the ultrastructural analysis.

\section{References}

Aragão-Craveiro A, Costa-Prado A, Gottlieb OR, Welersonde-Albuquerque PC 1970. Diarylheptanoids of Centrolobium species. Phytochesmistry 9: 18691875.

Araujo CAC, Alegrio LV, Leon LL 1999. Antileishmanial activity of compounds extracted and characterized from Centrolobium sclerophyllum. Phytochemistry 49: 751754.

Barros GMCC, Teixeira SP 2008. Estudo farmacobotânico de duas espécies de anileira (Indigofera suffruticosa e
Indigofera truxillensis, Leguminosae) com propriedades farmacológicas. Rev Bras Farmacogn 18: 287-294.

Bastos HM 1952. Contribuição para o conhecimento dendrológico das espécies do gênero Centrolobium. Arquivos do Serviço Florestal 6: 125-186.

Berlyn GP, Miksche JP 1976. Botanical microtechnique and cytochemistry. Ames: Iowa State University.

Bertoluzzi RLC, Miotto STS, Reis A 2006. Flora Ilustrada Catarinense: Leguminosas - Caesalpinioideae. Goiânia: Herbário Barbosa Rodrigues.

Corrêa MP 1984. Dicionário das plantas úteis do Brasil e das exóticas cultivadas. Rio de Janeiro: Imprensa Nacional.

Filardi FLR, Garcia FCP, Carvalho-Okano MR 2007. Espécies lenhosas de Papilionoideae (Leguminosae) na estação ambiental de Volta Grande, Minas Gerais, Brasil. Rodriguésia 58: 363-378.

Foster AS 1949. Practical plant anatomy. Princeton: D. Van Nostrand.

Gratieri-Sossella A 2005. Potencialidade ornamental e paisagística, caracterização morfo-anatômica e propagação de Erythrina cristagalli L. Passo Fundo, 176p. Dissertação de Mestrado, Programa de Pósgraduação em Agronomia, Universidade de Passo Fundo.

Hickey LJ 1974. Clasificación de la arquitectura de las hojas de dicotiledóneas. Bol Soc Argentina de Botánica 16: 1-26.

Johansen DA 1940. Plant microtechnique. New York: McGrawHill.

Judd WS, Campbell CS, Lellog EA, Stevens PF, Donoghue MJ 2008. Plant systematic. Sunderland: Sinauer.

Kraus JE, Arduin M 1997. Manual básico de métodos em morfologia vegetal. Rio de Janeiro: Edur.

Lima HC 1983-1985. Centrolobium Martius ex Bentham (Leguminosae - Papilionoidaeae) estudo taxonômico das espécies brasileiras extra-amazônicas. Arquivos do Jardim Botânico do Rio de Janeiro 27: 177-191.

Lima AK, Amorim ELC, Aquino TM, Lima CSA, Pimental RMM, Higino JS, Albuquerque UP 2003. Estudos farmacognósticos de Indigofera microcarpa Desv. (Fabaceae). Rev Bras Cienc Farm 39: 373-378.

Lorenzi H 2002. Árvores brasileiras: manual de identificação e cultivo de plantas arbóreas do Brasil. 4. ed. Nova Odessa: Instituto Plantarum.

Marquiafável FS, Barros GMCC, Teixeira SP 2007. Idioblastos secretores em espécies brasileiras de Indigofera L. (Leguminosae, Papilionoideae). R Bras Bioci 5: 354356.

Metcalfe CR, Chalk L 1950. Anatomy of the dicotyledons: leaves, stem, and wood in relation to taxonomy with notes on economic uses. Oxford: Clarendon.

O'Brien TP, Feder N, McCully ME 1964. Polychromatic staining of plant cell walls by toluidine blue O. Protoplasma 59: 368-373.

Oliveira F, Akisue G, Akisue MK 1991. Farmacognosia. São Paulo: Atheneu. 
Roeser KR 1972. Die Nadel der Schwarzkiefer-Massenprodukt und Kunstwerk der Natur. Mikroskosmos 61: 33-36.

Sass JE 1951. Botanical microtechnique. Ames: Iowa State College.

Souza VC, Lorenzi H 2005. Botânica sistemática. Nova Odessa: Instituto Plantarum.

Souza W 2007. Técnicas de microscopia eletrônica aplicadas às Ciências Biológicas. Rio de Janeiro: Sociedade Brasileira de Microscopia.

Tropicos 2009. Missouri Botanical Garden. http://www.tropicos. org, accessed in Apr 2009.

Ventura SJ, Menino GCO, Jesus FM, Mercadante-Simões MO, Ribeiro LM 2006. Anatomia foliar de Erythrina velutina Willd. (Fabaceae/Papilionoideae). LVII Congresso
Nacional de Botânica Congresso Nacional de Botânica. Gramado-RS, Brasil.

Von Martius KFP, Eichler AG, Urban I 1840-1906. Flora brasiliensis. v. 15. Monachii: Frid Fleischer.

\section{*Correspondence}

Márcia R Duarte

Programa de Pós-graduação em Ciências Farmacêuticas, Laboratório de Farmacognosia, Departamento de Farmácia, Universidade Federal do Paraná

Av. Pref. Lothário Meissner, 632, 80210-170, Curitiba-PR, Brazil

marciard@ufpr.br

Tel. +41 3360-4060 